\title{
EVALUASI SINTESIS EKSPRESI REALISTIK PADA SISTEM ANIMASI WAJAH 3D DENGAN TEKNOLOGI MOTION CAPTURE
}

\author{
Arif Sulistiyono, Agnes Karina Pritha Atmani, Samuel Gandang Gunanto, Troy \\ Program Studi Animasi, Fakultas Seni Media Rekam \\ Institut Seni Indonesia Yogyakarta \\ Jalan Parangtritis Km. 6,5 Sewon, Bantul, Yogyakarta \\ No. Hp.: 081312442888, 081380915096, 08562543431, 0811266218
}

E-mail:arif_sulistiyono@isi.ac.id, agneskarina@gmail.com, gandang@isi.ac.id,my_el2000@yahoo.com

\begin{abstract}
ABSTRAK
Wajah manusia memiliki bentuk dan ukuran yang unik, demikian pula model wajah karakter 3D. Selama ini proses animasi ekspresi wajah karakter virtual 3D sebagian besar masih dilakukan secara manual dengan menggerakkan rigging di setiap frame. Semakin banyak tokoh karakter yang dipakai, maka semakin banyak biaya produksi yang harus dikeluarkan. Belum adanya sistem transfer gerak ekspresi wajah yang murah meriah juga salah satu penyebab belum banyaknya studio yang menggunakan teknologi motion capture di Indonesia. Penelitian ini akan mengevaluasi implementasi sistem sintesis ekspresi wajah realistik pada sistem animasi wajah 3D dengan teknologi motion capture yang dibangun dari radial basis function (RBF) sebagai sebuah metode transfer penanda yang digunakan sebagai acuan pergerakan rigging di sistem klaster titik. Pengujian dilakukan dengan melakukan pendekatan ekspresi wajah menurut teori FACS dan kuesioner kualitas hasil sintesis. Hasil eksperimen menunjukkan, bahwa menurut teori FACS, syarat pembentukan ekspresi sudah dipenuhi dengan merujuk perubahan pada fitur wajah, namun pada implementasinya tidak selalu mampu menggambarkan sempurna kondisi yang diinginkan, yaitu rerata persentase wajah mudah dikenali sebesar 35,53\%. Oleh karena itu, pengaruh animator dalam kendali perbaikan ekspresi secara mikro ataupun penambahan unsur prinsip melebih-lebihkan (exaggeration) di dalam pembuatan animasi ekspresi wajah sangat penting untuk menghasilkan ekspresi wajah yang mudah dikenali oleh penonton.
\end{abstract}

Kata kunci: evaluasi, FACS, animasi wajah

\section{ABSTRACT}

Synthetic Evaluation of Realistic Facial Expression on 3D Facial Animation System with Motion Capture Technology. The human face has a unique shape and size, as well as a 3D character face model. The facial animation of $3 D$ virtual characters has been mostly done manually by moving the rigging in each frame. The more characters used, the more production costs that must be incurred. The absence of a cheap facial motion transfers system is also one of the reasons why not many studios are using motion capture technology in Indonesia. This research will evaluate the implementation of a facial expression synthetically using motion capture technology built from radial basis function (RBF) as a method of marker transfer as a reference for rigging movement in a point cluster system. Testing was done by doing an approach for facial expressions according to FACS theory and questionnaire of synthesis results. The experimental results showed that, according to FACS theory, the requirement of expression formation has been fulfilled by referring to changes in facial features, but the implementation is not always able to describe perfectly the desired condition, namely the average percentage of faces easily recognizable by $35.53 \%$. Therefore, the influence of animators in the control of micro expression improvements or the addition of exaggeration principle elements in the manufacture of facial animation is very important to produce facial expressions that are easily recognized by the audience.

Keywords: evaluation, facial animation, FACS 


\section{PENDAHULUAN}

Animasi wajah realistik merupakan aspek penting di lingkungan virtual 3D yang menghadirkan keberadaan karakter, baik manusia maupun yang menyerupainya. Pemanfaatannya meliputi industri game 3D, perangkat lunak interaktif, dan film animasi 3D. Bagaimanapun juga untuk menghasilkan animasi wajah yang baik diperlukan waktu yang lama bagi seorang animator ahli dikarenakan kompleksitas ekspresi wajah manusia yang merupakan bagian penting dalam pergerakan secara alamiah (Parke, 1972). Sampai saat ini bahkan perkembangan penelitian animasi wajah masih banyak dihasilkan, terutama untuk dua aspek penting: proses rigging wajah dan pemindahan ekspresi antardua buah karakter virtual 3D atau antarmanusia ke karakter 3D.

Belum adanya sistem transfer gerak ekspresi wajah yang murah meriah juga merupakan salah satu penyebab belum banyaknya studio yang menggunakan teknologi motion capture di Indonesia. Studio di Indonesia sebagian besar masih menggunakan pendekatan tradisional untuk menganimasikan ekspresi model wajah 3D. Pendekatan ini bergantung pada seorang seniman untuk menciptakan gerakan kunci dan kemudian menggabungkannya menjadi serangkaian gerakan ekspresi wajah. Kelangkaan sumber daya animasi yang ada sekarang menjadi kendala utama jika dikehendaki percepatan dalam proses produksi animasi. Proses tradisional masih banyak menggunakan teknik manual dengan pengubahan rigging secara frame-by-frame. Hal ini akan banyak menyita waktu dan membutuhkan sumber daya manusia yang besar sehingga meningkatkan biaya produksi sebuah animasi.
Ekspresi wajah yang ekspresif dan realistik tidak hanya meliputi pergerakan utama tulang wajah, namun juga meliputi variasi gerak alis, gerak hidung, dan perubahan dahi. Pergerakan-pergerakan tersebut ikut menentukan tingkat ekspresif dari sebuah ekspresi wajah. Oleh karena itu, penangkapan data motion capture harus meliputi pergerakanpergerakan detail tersebut supaya didapatkan data ekspresi yang ekspresif. Pembangkitan data detail pergerakan tambahan semi-otomatis telah dicoba menggunakan pendekatan Markov random fields yang disimulasikan dalam dua level, yaitu level koordinat pergerakan fitur wajah dan level perilaku fitur wajah yang independen (Ju \& Lee, 2008).

Wajah manusia memiliki bentuk dan ukuran yang unik, demikian pula model wajah karakter 3D. Karakter 3D dapat memiliki morfologi yang mirip dengan wajah manusia, dapat pula sangat berbeda dengan wajah manusia. Transformasi ruang radial basis function atau RBF digunakan untuk menentukan pergeseran titik fitur pada wajah karakter 3D berdasar pergerakan pada wajah manusia. Pergeseran titik fitur yang terjadi dalam wajah karakter 3D terjadi berdasar skala relatif antara posisi marker sumber dan posisi marker target (Lorenzo, Edge, King, \& Maddock, 2003) (Song, Choi, Seol, $\&$ Noh, 2011). Titik fitur dari wajah manusia mendefinisikan ruang sumber sedangkan titik fitur dari wajah karakter 3D mendefinisikan ruang target (Dutreve, Meyer, \& Bouakaz, 2008) (Li, Zhang, Zhou, \& Wei, 2013). Metode RBF dikembangkan pada tahun 1970-an. Metode ini digunakan untuk merekonstruksi fungsi dan untuk memecahkan persamaan diferensial parsial berdasarkan data yang tersebar (Hubbert, Gia, \& Morton, 2015). Referensi (Umenhoffer \& Tóth, 2012) menggunakan RBF untuk mendefinisikan 
relasi konfigurasi sumber serta target pada animasi wajah 3D yang berbasis pada posisi geometris tulang. RBF memiliki keunggulan dalam hal kecepatan proses pemetaan ulang titik fitur berbasis data penanda pada teknologi motion capture. Posisi ini akan berperan sebagai penanda acuan gerak yang dibangkitkan dengan bantuan letak tulang gerak pada wajah virtual 3D.

Pendekatan teori Facial Action Coding System (FACS) adalah sebuah deskripsi pergerakan otot wajah dan rahang/lidah yang diturunkan dari analisis anatomi wajah (Ekman $\&$ Friesen, 1978). FACS terdiri dari 44 action unit (AUs) dasar. Kombinasi action unit bebas menghasilkan ekpresi wajah seperti: terkejut, takut, senang, marah, sedih, dan jijik. Metode ini dikembangkan oleh Paul Ekman dan Wallace Friesen sebagai pengembangan dari metode bahasa mimik pada tahun 1978. Sistem FACS saat ini masih sering digunakan oleh para animator untuk merekonstruksi ekspresi wajah dengan memanfaatkan pengendali ekspresi di sistem animasi wajah secara deskriptif.

Penelitian kali ini merupakan salah satu bagian dari pengujian kerangka kerja sistem sintesis ekspresi wajah 3D dengan memaparkan kajian hasil secara teoritis dan kuisioner untuk menilai keberhasilan proses transfer ekspresi emosi dari manusia ke karakter animasi 3D. Luaran eksperimentasi ini diharapkan mampu menyumbangkan sebuah evaluasi hasil implementasi sintesis ekspresi wajah realistik $3 \mathrm{D}$ yang telah teruji secara teoretis dan kualitas praktikal.

\section{METODE EKSPERIMEN}

Proses pemetaan ulang adalah proses transformasi marker berbasis pada ruang koordinat. Pemetaan ulang dapat didefinisikan sebagai proses menentukan lokasi titik marker pada wajah karakter animasi berdasar pada perubahan posisi marker pada wajah manusia yang terjadi dikarenakan terbentuknya sebuah ekspresi. Proses ini berusaha untuk menciptakan ekspresi pada karakter sesuai dengan ekspresi sumber, yaitu wajah manusia dengan menghitung nilai transformasi titik penanda pada manusia ke model wajah animasi 3D (Pighin \& Lewis, 2006).

Dengan kondisi wajah manusia dan wajah model 3D yang memiliki ukuran dan bentuk yang berbeda, transformasi ruang RBF dapat menentukan pergerakan titik fitur pada wajah model $3 \mathrm{D}$ sesuai dengan pergerakan titik fitur pada wajah sumber animasi. Gerak titik fitur yang terjadi pada wajah model 3D disesuaikan pada skala relatif antara titik marker pada wajah sumber dan titik fitur pada wajah target animasi (Lorenzo, Edge, King, \& Maddock, 2003) (Song, Choi, Seol, \& Noh, 2011). Titik marker pada wajah sumber animasi mendefinisikan ruang sumber sedangkan titik fitur pada wajah model 3D mendefinisikan ruang target (Dutreve, Meyer, \& Bouakaz, 2008) (Li, Zhang, Zhou, \& Wei, 2013).

Sintesis ekspresi wajah manusia dilakukan dengan bantuan kamera dengan sumber wajah yang telah ditandai dengan titik penanda atau marker. Proses transformasi dari ruang koordinat $2 \mathrm{D}$ ke koordinat $3 \mathrm{D}$ dilakukan dengan metode retargeting menggunakan teknik radial basis function yang disingkat sebagai RBF (Troy, Pranowo, \& Gunanto, 2016). Proses transformasi dibagi menjadi dua tahap, yaitu pembelajaran dan pengujian. Pada tahap pembelajaran, titik marker pada wajah sumber dengan ekspresi netral disimpan dan dikorelasikan dengan titikfiturpada wajahmodel 3D yang juga berekspresi netral. Selanjutnya, transformasi ruang RBF menghasilkan bobot 
tiap titik fitur pada koordinat (x, y, z). Pada tahap pengujian, berbagai ekspresi yang menampilkan emosi dari wajah sumber animasi ditangkap pergerakan titik marker-nya. Setelah semua dicatat, transformasi dihitung dengan menggunakan bobot yang telah diperoleh pada tahap pembelajaran sehingga lokasi titik fitur pada wajah model 3D yang telah mengalami pergerakan dapat dipetakan ulang. Secara skematis, proses transformasi ruang $\mathrm{RBF}$ digambarkan pada Gambar 1. Data ekstraksi penanda wajah yang telah diberi parameter akan digunakan untuk membangun matrik bobot transformasi yang akan digunakan untuk melakukan proses retargeting pose ekspresiekspresi lainnya.

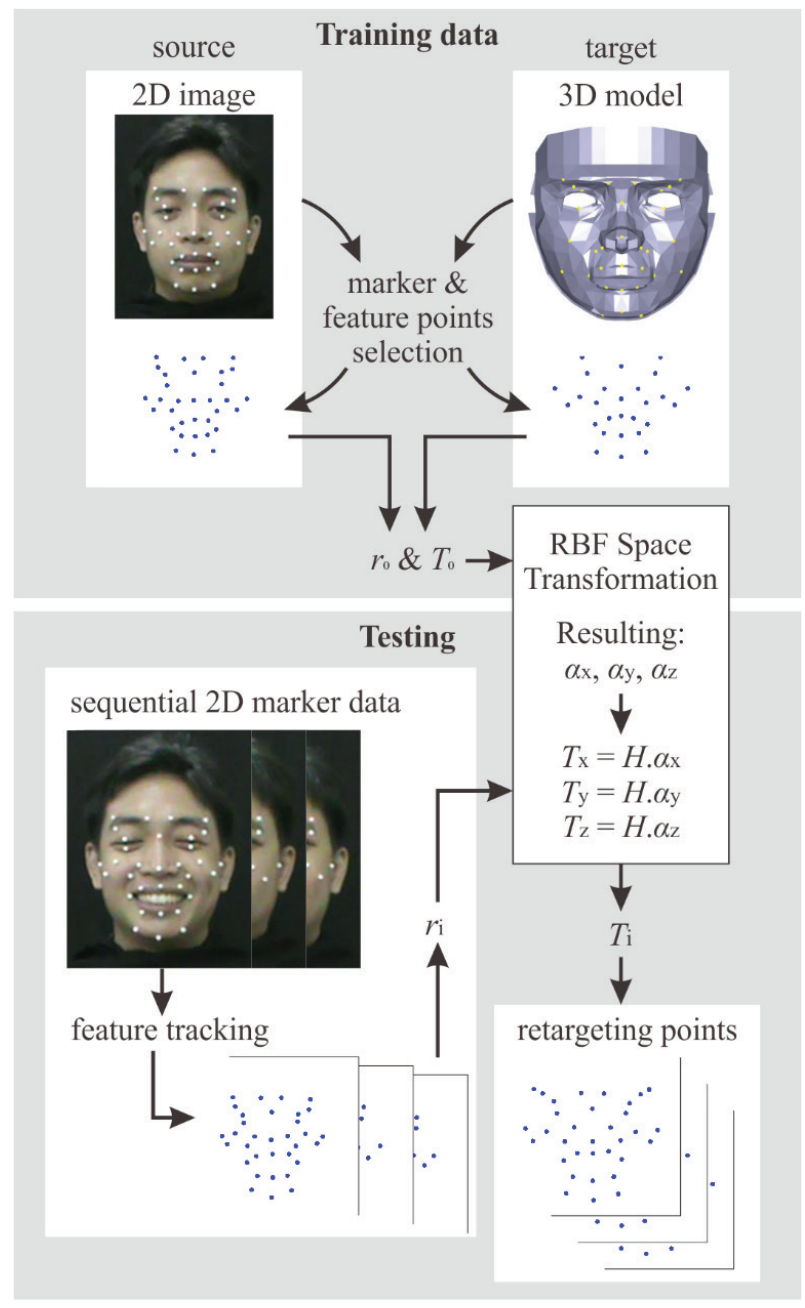

Gambar 1. Alur sintesis ekspresi wajah dengan metode retargeting $\mathrm{RBF}$
Persamaan RBF yang digunakan adalah sebagai berikut.

$F(x)=\sum_{i=1}^{n} \alpha_{i} \cdot \Phi\left(\left\|x-x_{i}\right\|\right)$

Nilai $\phi$ hanya tergantung pada jarak dari pusat dan dengan demikian disebut radial (2). Radial ini adalah jarak antara titik fitur pada citra wajah 2D.

$\phi\left(\left\|x y_{i}-x y_{j}\right\|\right)=\sqrt{\left(\left\|x y_{i}-x y_{j}\right\|\right)^{2}+r^{2}}$

Persamaan(6) adalah RBF Multiquadric, variasi yang dievaluasi pada penelitian ini adalah dengan variasi penerapan fungsi radial pada Persamaan (2). Nilai xy adalah posisi titik marker pada koordinat 2D. Menggunakan teorema Pitagoras, jarak antar titik marker dapat diketahui. Nilai $r$ ditentukan berdasarkan jarak terpendek dari semua titik marker pada wajah sumber animasi (3).

$r=m i n_{i \neq j}\left(\left\|x y_{i}-x y_{j}\right\|\right)$

Nilai $\quad \phi\left(\left\|x y_{i}-x y_{j}\right\|\right) \quad$ digunakan untuk membangun matriks $H$. Lalu nilai bobot $(\alpha)$ untuk setiap koordinat $(\mathrm{x}, \mathrm{y}, \mathrm{z})$ dari wajah model 3D diperoleh (4):

$T_{x}=H . \alpha_{x}, T_{y}=H . \alpha_{y}, T_{z}=H . \alpha_{z}$

Jika diketahui

$T_{x}=\left(t_{1}^{x}, t_{2}^{x}, t_{3}^{x}, \ldots, t_{n}^{x}\right), \quad T_{y}=\left(t_{1}^{y}, t_{2}^{y}, t_{3}^{y}, \ldots, t_{n}^{y}\right)$, dan $T_{z}=\left(t_{1}^{z}, t_{2}^{z}, t_{3}^{z}, \ldots, t_{n}^{z}\right)$, maka dengan menerapkan eliminasi Gauss (back substitution) dari Persamaan (1) diperoleh:

$\alpha_{x}=H^{-1} \cdot T_{x}$,
$\alpha_{y}=H^{-1} \cdot T_{y}$,
$\alpha_{z}=H^{-1} \cdot T_{z}$ 
Setelah matrik $\mathrm{H}$ dan bobot masingmasing koordinat (x, y, z) (5) diperoleh, pemetaan ulang titik fitur dapat dihitung dengan cepat untuk setiap posisi titik marker berdasar gerakan wajah sumber animasi menggunakan Persamaan (6).

$$
\begin{aligned}
& F(x)=\sum_{i=1}^{n} \alpha_{i}^{x} \cdot \Phi\left(\left\|x y-x y_{i}\right\|\right), \\
& F(y)=\sum_{i=1}^{n} \alpha_{i}^{y} \cdot \Phi\left(\left\|x y-x y_{i}\right\|\right), \\
& F(z)=\sum_{i=1}^{n} \alpha_{i}^{z} \cdot \Phi\left(\left\|x y-x y_{i}\right\|\right)
\end{aligned}
$$

Pada tahap pengujian, citra 2D yang berurutan diekstrak untuk menemukan lokasi titik marker pada wajah sumber. Setelah diperoleh nilai jarak radial kemudian nilai bobot $(\alpha)$ serta matrik $H(\phi)$ dari proses pembelajaran, transformasi ruang RBF akan mengestimasi lokasi (x, y, z) dari titik fitur wajah model 3D. Sehingga wajah model 3D masih memiliki kedalaman dan mempertahankan bentuk 3D-nya.

Jika semua titik fitur sudah terpetakan sebagai acuan pergerakan, maka perubahan bentuk wajah dapat divisualisasikan transisinya dari data tangkapan kamera sampai hasil implementasinya pada model karakter wajah 3D pada Gambar 2.

Hasil implementasi tersebut kemudian akan diujikan menggunakan teori FACS dengan mengacu pada perubahan titik fitur yang telah ditandai dengan nomor dan dibandingkan dengan ketentuan perubahan ekspresi pada tabel action unit(AU) FACS, Tabel 1 dan Tabel 2.

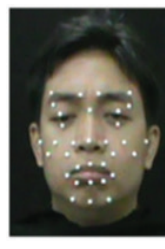

(a)

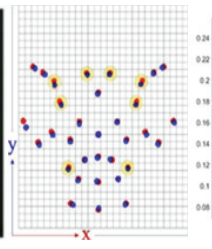

(b)

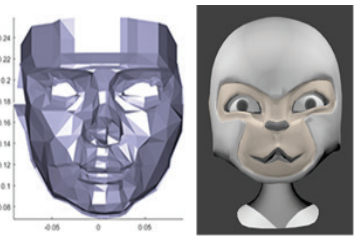

(c)

(d)
Gambar 2. Visualisasi penampakan wajah sedih dari sumber asli tangkapan kamera(a), hasil ekstraksi titik penanda dan retargetting $\mathrm{RBF}(\mathrm{b})$, implementasi perubahan pada model wajah 3D manusia(c) serta model wajah 3D karakter kartun(d).

Tabel 1. Contoh action units wajah tunggal

\begin{tabular}{cl}
\hline AU & \multicolumn{1}{c}{ FACS Name } \\
\hline 1 & Alis dalam naik \\
2 & Alis luar naik \\
4 & Alis turun \\
5 & Bagian atas kelopak mata terangkat \\
6 & Pipi naik \\
9 & Hidung berkerut \\
10 & Bibir atas naik \\
12 & Sudut kelopak mata tertarik \\
14 & Lesung pipi \\
15 & Sudut bibir tertekan \\
16 & Bibir bawah tertekan \\
17 & Dahi naik \\
20 & Bibir meregang \\
23 & Bibir menutup kencang \\
\hline 26 & Rahang turun \\
\hline
\end{tabular}

Sumber: Ekman \& Friesen, 1978

Tabel 2. Contoh himpunan action units untuk ekpresi dasar

\begin{tabular}{ll}
\hline Ekspresi Dasar & Keterlibatan Action Unit \\
\hline Terkejut & AU1, 2, 5, 15, 16, 20, 26 \\
Takut & AU1, 2, 4, 5, 15, 20, 26 \\
Marah & AU2, 4, 7, 9, 10, 20, 26 \\
Senang & AU1, 6, 12, 14 \\
Sedih & AU1, 4, 15, 23 \\
\hline Jijik & AU9, 15, 16 \\
\hline
\end{tabular}

Sumber: Ekman \& Friesen, 1978

Secara sederhana, FACS banyak digunakan dengan basis otot atau pendekatan berbasisototsemu. Metodeanimasimenggunakan model otot untuk mengatasi batasan interpolasi dan menghasilkan variasi ekspresi wajah yang 
luas. Permodelan otot berbasis fisik secara matematis menjabarkan atribut dan perilaku kulit manusia, tulang, dan sistem otot. Secara berlainan, model otot semu meniru dinamisasi kulit manusia dengan deformasi geometris secara heuristik. Selain popularitasnya, ada juga beberapa keuntungan menggunakan FACS (Essa, Basu, Darrell, \& Pentland, 1996). Pertama, AUs murni pola lokal sementara actual facial motion sangat jarang terlokalisasi. Kedua, FACS menawarkan deskripsi gerak spasial tetapi bukan komponen temporal. Pada sumber temporal, efek koartikulasi hilang di sistem FACS.

\section{HASIL DAN PEMBAHASAN}

Percobaan ini menggunakan sumber data tangkapan kamera tunggal yang memiliki tampilan wajah hadap depan. Informasi ekspresi wajah ditandai dengan letak penanda yang ditempelkan di wajah manusia. Tanda ini kemudian akan diekstrak dan digunakan dalam proses transfer ekspresi wajah ke model 3D dengan metode radial basis function (RBF). Contoh wajah sumber yang telah ditandai dan diberi informasi posisi marker dapat dilihat di Gambar 3. Sedangkan data titik rigging di model 3D sebagai target transfer ekspresi wajah dapat dilihat pada Gambar 4. Konsistensi parameter penanda antarsumber dan target adalah kunci ketepatan transfer ekspresi wajah.
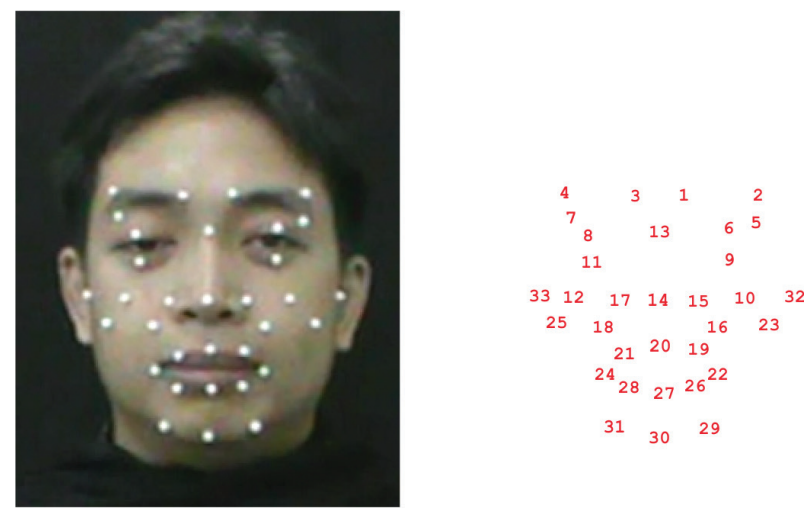

Gambar 3. Ekspresi sumber hasil tangkapan kamera 2D berikut 33 parameter nomor penanda yang akan diekstrak.
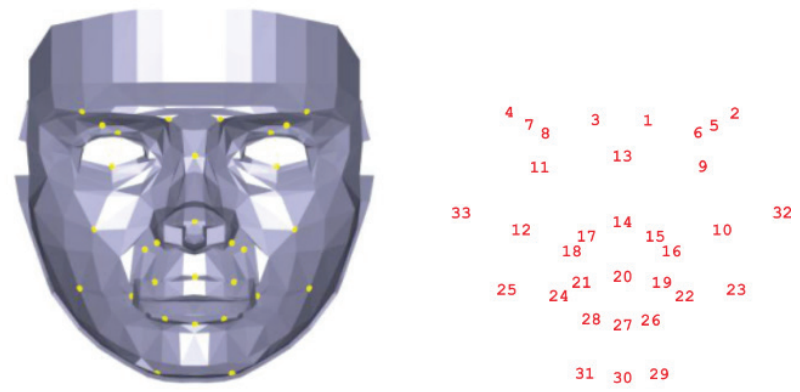

Gambar 4. Model wajah 3D sebagai target dengan 33 titik penanda yang menjadi acuan perubahan ekspresi wajah.

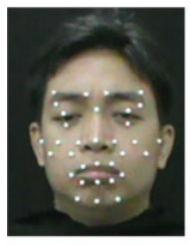

a

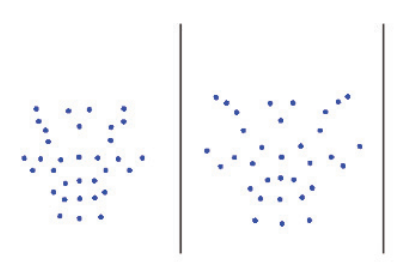

b $\mathrm{c}$

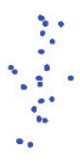

d
Gambar 5. Proses retargeting RBF ekspresi sedih:

(a) citra 2D tangkapan kamera; (b) ekstraksi penanda pada wajah 2D; (c) hasil retargeting penanda pada model wajah 3D tampak depan; (d) hasil retargeting penanda pada model wajah 3D tampak samping.

Data yang menjadi sumber sintesis meliputi enam ekspresi dasar, yaitu terkejut, takut, marah, senang, sedih, dan jijik. Gambaran hasil proses transfer ekspresi dengan metode RBF Multiquadric untuk ekspresi sedih dapat dilihat pada Gambar 5.

Setelah perhitungan retargeting didapatkan, visualisasi analisis hasil untuk masing-masing ekspresi dapat dievaluasi berdasarkan teori FACS sebagai berikut.

\section{Ekspresi Sedih}

Setelah lokasi titik marker diketahui, transformasi ruang RBF akan melakukan pemetaan ulang lokasi titik fitur yang baru sesuai dengan citra wajah masukan. Berdasarkan Lucey et al. ekspresi sedih memiliki kriteria AU: kombinasi antara alis $(1,2,3,4,5,7)$ yang diturunkan dan ujung bibir $(22,24)$ yang ditarik ke bawah (Gambar 6a) (Lucey, Cohn, Kanade, Saragih, \& Ambadar, 2010). Pada pergeseran titik marker citra wajah 2D (Gambar 6b) ditunjukkan 
dengan titik marker pada alis $(1,2,3,4,5,7)$ yang diturunkan dan ujung bibir $(22,24)$ yang ditarik ke bawah. Demikian pula pada hasil transformasi ruang RBF (Gambar 6c) terjadi pergeseran titik fitur pada alis $(1,2,3,4,5,7)$ yang diturunkan dan ujung bibir $(22,24)$ yang ditarik ke bawah.

Gambar 6b dan Gambar 6c adalah proses yang terjadi pada perhitungan transformasi ruang RBF untuk ekspresi sedih. Gambar $6 b$ menunjukkan pergeseran titik marker citra wajah 2D dari ekspresi netral (merah) ke ekspresi sedih (biru). Gambar 6c menunjukkan pergeseran titik fitur wajah model 3D dari ekspresi netral (merah) ke titik hasil pemetaan transformasi ruang RBF (biru).

\section{Ekspresi Senang}

Ekspresi senang memiliki kriteria AU: sudut ujung bibir $(22,24)$ yang ditarik melebar dan naik (Gambar 7a). Pada pergeseran titik marker citra wajah 2D (Gambar 7b) ditunjukkan dengan titik marker pada ujung bibir $(22,24)$ yang melebar dan naik. Demikian pula pada hasil transformasi ruang RBF (Gambar 7c) terjadi pergeseran titik fitur pada ujung bibir $(22,24)$ yang melebar dan naik.

Gambar 7b dan Gambar 7c adalah proses yang terjadi dari perhitungan transformasi ruang RBF pada ekspresi senang. Gambar 7b menunjukkan pergeseran titik marker citra wajah 2D dari ekspresi netral (merah) ke ekspresi senang (biru). Gambar 7c menunjukkan pergeseran titik fitur wajah model 3D dari ekspresi netral (merah) ke titik hasil pemetaan transformasi ruang RBF (biru).

\section{Ekspresi Marah}

Ekspresi marah memiliki kriteria AU: bibir $(19,20,21,22,24,26,27,28)$ yang merapat dan ditarik ke dalam (Gambar 8a). Pada pergeseran titik marker citra wajah 2D (Gambar 8b) ditunjukkan dengan titik marker pada lingkaran bibir $(19,20,21,22,24,26,27,28)$ yang merapat dan mengecil. Demikian pula pada hasil transformasi ruang RBF $(8 \mathrm{c})$ terjadi pergeseran titik fitur pada lingkaran bibir $(19,20,21,22,24$, $26,27,28)$ yang merapat dan mengecil.

Gambar 8b dan Gambar 8c adalah proses yang terjadi dari perhitungan transformasi ruang RBF pada ekspresi marah. Gambar 8b menunjukkan pergeseran titik marker citra wajah 2D dari ekspresi netral (merah) ke ekspresi marah (biru). Gambar 8c menunjukkan pergeseran titik fitur wajah model 3D dari ekspresi netral (merah) ke titik hasil pemetaan transformasi ruang RBF (biru).

\section{Ekspresi Jijik}

Ekspresi jijik memiliki kriteria AU: hidung $(14,15,16,17,18)$ mengecil dan bibir atas $(19,20,21)$ terangkat (Gambar 9a). Pada pergeseran titik marker citra wajah 2D (Gambar 9b) ditunjukkan dengan titik marker pada area hidung $(14,15,16,17,18)$ yang merapat dan bibir atas $(19,20,21)$ yang dinaikkan. Demikian pula pada hasil transformasi ruang $\mathrm{RBF}$ (Gambar 9c) terjadi pergeseran titik fitur pada area hidung $(14,15,16,17,18)$ yang merapat dan bibir atas $(19,20,21)$ yang dinaikkan.

Gambar 9b dan Gambar 9c adalah proses yang terjadi dari perhitungan transformasi ruang RBF pada ekspresi jijik. Gambar 9b menunjukkan pergeseran titik marker citra wajah 2D dari ekspresi netral (merah) ke ekspresi jijik (biru). Gambar 9c menunjukkan pergeseran titik fitur wajah model 3D dari ekspresi netral (merah) ke titik hasil pemetaan transformasi ruang RBF (biru).

\section{Ekspresi Takut}

Ekspresi takut memiliki kriteria AU: alis $(1,2,3,4,5,6,7,8)$ yang berkumpul dan 
diturunkan (Gambar 10a). Pada pergeseran titik marker citra wajah 2D (Gambar 10b) ditunjukkan dengan titik marker pada alis bagian dalam (6, 8) yang merapat dan alis $(1,2,3,4,5,7)$ yang merendah. Demikian pula pada hasil transformasi ruang RBF (Gambar 10c) terjadi pergeseran titik fitur pada alis bagian dalam $(6,8)$ yang merapat dan alis $(1,2,3,4,5,7)$ yang merendah.

Gambar 10b dan Gambar 10c adalah proses yang terjadi dari perhitungan transformasi ruang RBF pada ekspresi takut. Gambar 10b menunjukkan pergeseran titik marker citra wajah 2D dari ekspresi netral (merah) ke ekspresi takut (biru). Gambar 10c menunjukkan pergeseran titik fitur wajah model 3D dari ekspresi netral (merah) ke titik hasil pemetaan transformasi ruang RBF (biru).

\section{Ekspresi Terkejut}

Ekspresi terkejut memiliki kriteria AU: alis $(1,2,3,4,5,7)$ yang terangkat dan bibir $(19,20$, $21,22,24)$ atas yang naik dan melebar (Gambar 11a). Pada pergeseran titik marker citra wajah 2D (Gambar 11b) ditunjukkan dengan titik marker pada alis $(1,2,3,4,5,7)$ dan alis bagian dalam $(6,8)$ yang naik serta bibir atas $(19,20,21,22$, 24) yang naik dan melebar. Demikian pula pada hasil transformasi ruang RBF (Gambar 11c) terjadi pergeseran titik fitur pada alis $(1,2,3,4,5,7)$ dan alis bagian dalam $(6,8)$ yang naik serta bibir atas $(19,20,21,22,24)$ yang naik dan melebar.

Gambar 11b dan Gambar 11c adalah proses yang terjadi dari perhitungan transformasi ruang RBF pada ekspresi terkejut. Gambar 11b menunjukkan pergeseran titik marker citra wajah 2D dari ekspresi netral (merah) ke ekspresi terkejut (biru). Gambar 11c menunjukkan pergeseran titik fitur wajah model 3D dari ekspresi netral (merah) ke titik hasil pemetaan transformasi ruang RBF (biru).
Setelah semua syarat pembentukan ekspresi sudah dipastikan memenuhi teori FACS, maka dilakukanlah implementasi perubahan bentuk wajah ke masing-masing ekspresi dan didapatkan hasil seperti tampak pada Gambar 12. Keenam ekspresi tersebut kemudian dipaparkan dalam bentuk kuesioner tertulis dalam penyajian gambar statis dan elektronik dalam bentuk penayangan video. Responden sejumlah 76 orang sudah menyaksikan hasil implementasi tersebut sekaligus mengisi kuesioner yang diberikan.

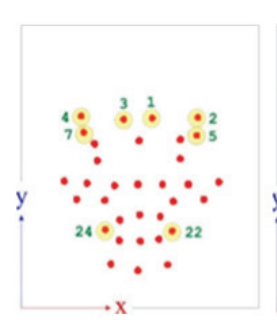

(a)

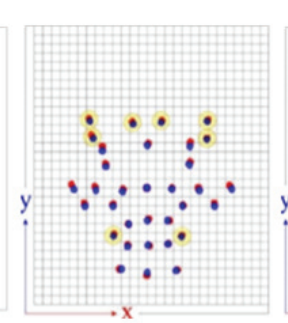

(b)

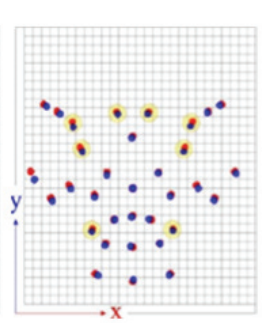

(c)
Gambar 6. Posisi titik marker FACS yang bergeser pada ekspresi sedih: (a) menurut teori FACS; (b) Hasil ekstraksi pada wajah manusia; (c) Hasil retargeting $\mathrm{RBF}$ di target wajah model 3D.

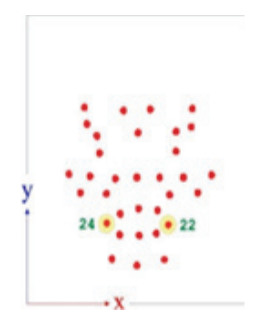

(a)

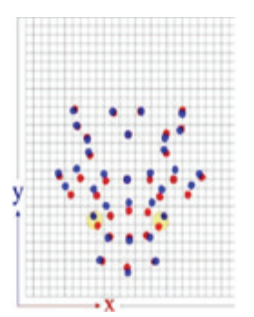

(b)

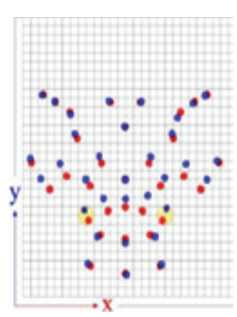

(c)
Gambar 7. Posisi titik marker FACS yang bergeser pada ekspresi senang: (a) menurut teori FACS;

(b) Hasil ekstraksi pada wajah manusia; (c) Hasil retargeting $\mathrm{RBF}$ di target wajah model $3 \mathrm{D}$.

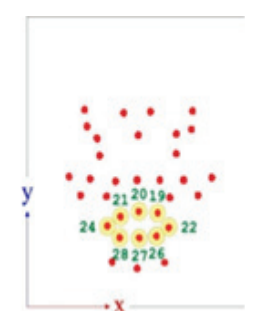

(a)

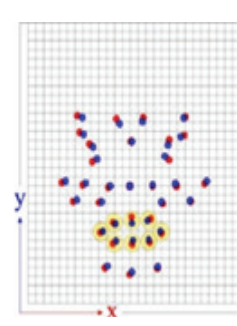

(b)

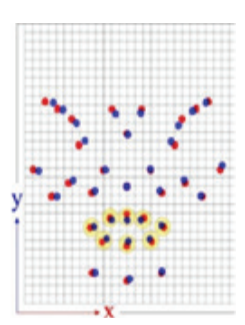

(c)
Gambar 8. Posisi titik marker FACS yang bergeser pada ekspresi marah: (a) menurut teori FACS;

(b) Hasil ekstraksi pada wajah manusia; (c) Hasil retargeting $\mathrm{RBF}$ di target wajah model $3 \mathrm{D}$. 
(g)
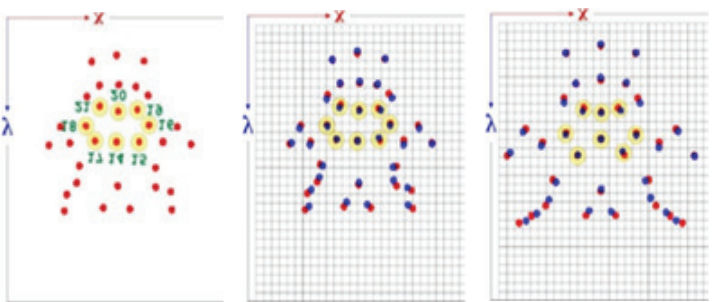

Gambar 9. Posisi titik marker FACS yang bergeser pada ekspresi jijik: (a) menurut teori FACS; (b) Hasil ekstraksi pada wajah manusia; (c) Hasil retargeting $\mathrm{RBF}$ di target wajah model 3D.

(g)

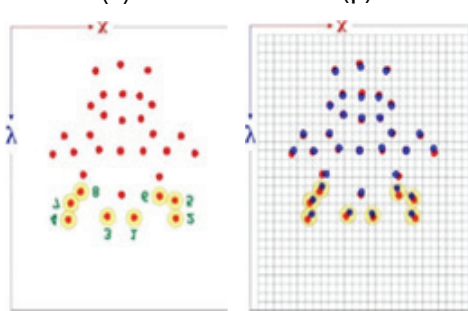

Gambar 10. Posisi titik marker FACS yang bergeser pada ekspresi takut: (a) menurut teori FACS; (b) Hasil ekstraksi pada wajah manusia; (c) Hasil retargeting RBF di target wajah model 3D.

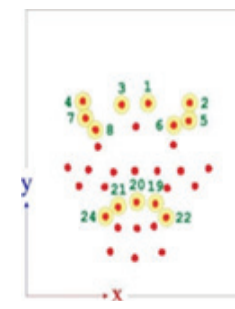

(a)

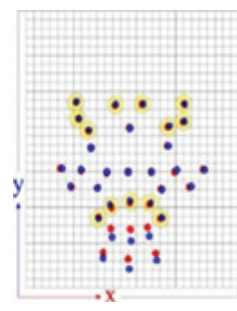

(b)

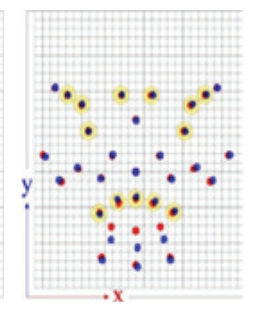

(c)
Gambar 11. Posisi titik marker FACS yang bergeser pada ekspresi terkejut: (a) menurut teori FACS; (b) Hasil ekstraksi pada wajah manusia; (c) Hasil retargeting $\mathrm{RBF}$ di target wajah model 3D.

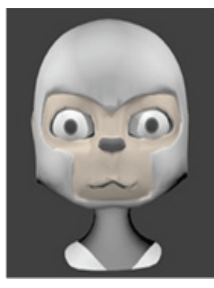

(a)

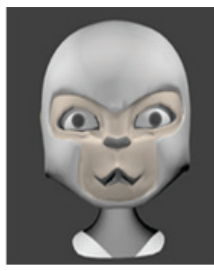

(d)

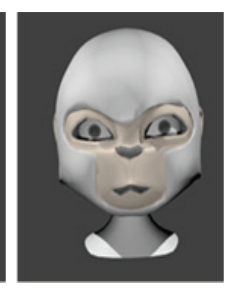

(b)

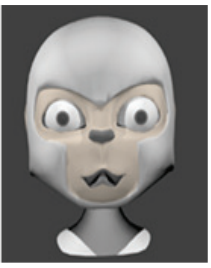

(e)

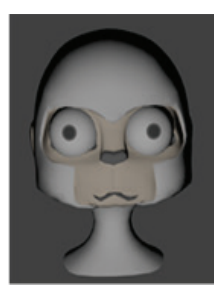

(c)

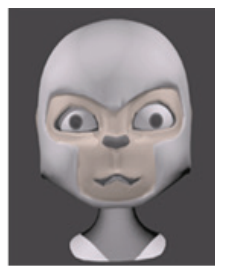

(f)
Gambar 12. Visualisasi hasil transfer ekspresi ke model wajah 3D: a) Jijik; b) Marah; c) Takut; d) Senang; e) Terkejut; f) Sedih.
Hasil yang didapatkan secara umum menunjukkan bahwa dari keenam ekspresi tersebut, ekspresi terkejut memiliki persentase paling tinggi mudah dikenali, yaitu $63,16 \%$. Adapun ekspresi marah 42,11\%, ekspresi takut $34,21 \%$, ekspresi senang $31,58 \%$, ekspresi jijik $21,05 \%$, serta ekspresi sedih $21,05 \%$. Rerata persentase wajah mudah dikenali sebesar $35,53 \%$.

\section{SIMPULAN}

Berdasarkan hasil evaluasi pada enam ekspresi dasar yang digunakan pada tahap pengujian, yaitu sedih, senang, marah, takut, jijik dan terkejut, hasil retargeting dapat memetakan ulang titik fitur pada wajah model 3D sesuai dengan pergerakan titik marker pada citra wajah 2D yang menjadi wajah sumber animasi. Perubahan ekspresi yang terjadi sudah sesuai dengan persyaratan minimal pada perubahan FACS, sehingga ekspresi yang terbentuk sesuai dengan teori ekspresi realistik menurut FACS.

Transformasi ruang RBF dapat mengatasi perbedaan ruang dimensi koordinat bentuk wajah sumber animasi dengan wajah target animasi. Hal ini ditunjukkan dengan posisi titik marker pada citra wajah yang tidak simetris ternyata tidak merusak pemetaan ulang titik fitur pada wajah model 3D.

Persentase hasil kuesioner tentang implementasi sintesis ekspresi wajah ke model 3D menunjukkan secara gamblang bahwa visualisasi ekspresi wajah walaupun telah memenuhi syarat teoretis, ternyata pada implementasinya tidak selalu mampu menggambarkan sempurna kondisi yang diinginkan, yaitu rerata persentase wajah mudah dikenali sebesar 35,53\%. Oleh karena itu, pengaruh animator dalam kendali perbaikan 
ekspresi secara mikro ataupun penambahan unsur prinsip melebih-lebihkan (exaggeration) di dalam pembuatan animasi ekspresi wajah sangat penting untuk menghasilkan ekspresi wajah yang mudah dikenali oleh penonton.

\section{KEPUSTAKAAN}

Chenoweth, M.E. (2012). “A Local Radial Basis Function Method for the Numerical Solution of Partial Differential Equations". Theses, Dissertations and Capstones, Paper 243.

Dutreve, L., Meyer, A., \& Bouakaz, S. (2008). "Feature Points Based Facial Animation Retargeting". ACM Symposium on Virtual Reality Software and Technology, (hal. tware and technology, 2008, pp.197-200). Bordeaux, France.

Ekman, P., \& Friesen, W. V. (1978). Facial Action Coding System: A Technique for the Measurement of Facial Movement. Palo Alto: Consulting Psychologists Press.

Essa, I., Basu, S., Darrell, T., \& Pentland, A. (1996). "Modeling, tracking and interactive animation of faces and heads using input from video". Proceedings of Computer Animation, (hal. 85-94).

Hubbert, S., Gia, Q. L., \& Morton, T. M. (2015). Spherical Radial Basis Functions, Theory and Applications. (N. Bellomo, M. Benzi, P. E. Jorgensen, T. Li, R. Melnik, O. Scherzer, P. Zhang, Penyunt.) Cham Heidelberg New York Dordrecht London: Springer.

Ju, E., \& Lee, J. (2008). "Expressive Facial Gestures From Motion Capture Data". Eurographics.

Kwon, J.-Y., \& Lee, I.-K. (2012). "The Squashand-Stretch Stylization for Character Motions". IEEE Transactions on Visualization and Computer Graphics Vol 18, 488-500.

Li, B., Zhang, Q., Zhou, D., \& Wei, X. (2013). "Facial Animation Based on Feature Points”. TELKOMNIKA, 11(3), 16971706.
Lorenzo, M. S., Edge, J. D., King, S. A., \& Maddock, S. (2003). "Use and Re-use of Facial Motion Capture Data". Vision, Video, and Graphics, 1-8.

Lucey, P., Cohn, J. F., Kanade, T., Saragih, J., \& Ambadar, Z. (2010). "The Extended Cohn-Kanade Dataset $(\mathrm{CK}+)$ : A complete dataset for action unit and emotion-specified expression". IEEE Computer Society Conference on Computer Vision and Pattern Recognition (hal. 94-101). San Francisco, CA: IEEE.

Parke, F. (1972). "Computer Generated Animation of Face". Proceedings of the ACM annual conference (hal. 451-457). ACM.

Pighin, F., \& Lewis, J. P. (2006). Facial Motion Retargeting. SIGGRAPH.

Song, J., Choi, B., Seol, Y., \& Noh, J. (2011). Characteristic facial retargeting. Comp. Anim. Virtual Worlds, 22, 187-194.

Troy, Pranowo, \& Gunanto, S. G. (2016). “2D to 3D Space Transformation for Facial Animation Based on Marker Data". The 6th International Annual Engineering Seminar (InAES). Yogyakarta.

Umenhoffer, T., \& Tóth, B. (2012). "Facial animation retargeting framework using radial basis". Sixth Hungarian Conference on Computer Graphics and Geometry. Budapest. 